OPEN ACCESS

Edited by:

Olivier Lamotte,

UMR Agroécologie, France

Reviewed by:

Walter Chitarra,

National Research Council, Italy Giorgio Gambino,

National Research Council, Italy

${ }^{*}$ Correspondence:

Yan Xu

yan.xu@nwsuaf.edu.cn

Qiao-Chun Wang

qiaochunwang@nwsuaf.edu.cn

Specialty section: This article was submitted to

Plant Physiology,

a section of the journal

Frontiers in Physiology

Received: 20 December 2015

Accepted: 19 May 2016

Published: 02 June 2016

Citation:

Cui Z-H, Bi W-L, Hao X-Y, XU Y, Li P-M, Walker MA and Wang Q-C (2016) Responses of In vitro-Grown Plantlets Nitis vinifera) to Grapevine leafroll-Associated Virus-3 and PEG-Induced Drought Stress.

Front. Physiol. 7:203

doi: 10.3389/fphys.2016.00203

\section{Responses of In vitro-Grown Plantlets (Vitis vinifera) to Grapevine leafroll-Associated Virus-3 and PEG-Induced Drought Stress}

\author{
Zhen-Hua Cui ${ }^{1,2}$, Wen-Lu Bi ${ }^{1}$, Xin-Yi Hao ${ }^{1}$, Yan Xu ${ }^{1 *}$, Peng-Min $\mathrm{Li}^{1}$, M. Andrew Walker ${ }^{2}$ \\ and Qiao-Chun Wang ${ }^{1 *}$ \\ 1 State Key Laboratory of Crop Stress Biology for Arid Areas, Key Laboratory of Genetic Improvement of Horticultural Crops \\ of Northwest China, College of Horticulture, Northwest A\&F University, Yangling, China, ${ }^{2}$ Department of Viticulture and \\ Enology, University of California, Davis, Davis, CA, USA
}

Stresses caused by viral diseases and drought have long threatened sustainable production of grapevine. These two stresses frequently occur simultaneously in many of grapevine growing regions of the world. We studied responses of in vitro-grown plantlets (Vitis vinifera) to Grapevine leafroll associated virus-3 (GLRaV-3) and PEG-induced drought stress. Results showed that stress induced by either virus infection or drought had negative effects on vegetative growth, caused significant decreases and increases in total soluble protein and free proline, respectively, induced obvious cell membrane damage and cell death, and markedly increased accumulations of $\mathrm{O}_{2}^{--}$and $\mathrm{H}_{2} \mathrm{O}_{2}$. Co-stress by virus and drought had much severer effects than single stress on the said parameters. Virus infection alone did not cause significant alternations in activities of POD, ROS, and SOD, and contents of MDA, which, however, markedly increased in the plantlets when grown under single drought stress and co-stress by the virus and drought. Levels of ABA increased, while those of IAA decreased in the plantlets stressed by virus infection or drought. Simultaneous stresses by the virus and drought had co-effects on the levels of ABA and IAA. Up-regulation of expressions of ABA biosynthesis genes and down-regulation of expressions of IAA biosynthesis genes were responsible for the alternations of ABA and IAA levels induced by either the virus infection or drought stress and co-stress by them. Experimental strategies established in the present study using in vitro system facilitate investigations on 'pure' biotic and abiotic stress on plants. The results obtained here provide new insights into adverse effects of stress induced by virus and drought, in single and particularly their combination, on plants, and allow us to re-orientate agricultural managements toward sustainable development of the agriculture.

Keywords: cell damage, drought, grapevine leafroll virus, physiological metabolism, plant hormones, Vitis vinifera

\section{INTRODUCTION}

Stresses caused by abiotic and biotic factors have long threatened sustainable development of agricultural production. Drought, one of the greatest abiotic stresses, was reported to cause agricultural losses of 50 billion dollars between 1980 and 2012 in United States alone (Suzuki et al., 2014). It is estimated that more than $6 \%$ of the world's land and $30 \%$ of the world's irrigated 
areas also face salinity problems (UNESCO Water Portal, 2007). Viral disease, a biotic stress, causes serious economic losses to agricultural crops (Hadidi and Barba, 2011).

The influence of stress by either virus infection (Sampol et al., 2003; Moutinho-Pereira et al., 2012; Li et al., 2013; Cui et al., 2015) or drought (Zhu, 2002; Suzuki et al., 2014) has been well-demonstrated on plant development, growth, photosynthetic capability and various physiological metabolisms, eventually resulting in reduction of crop yield and quality. However, studies on their combining effects have been quite limited (Atkinson and Urwin, 2012; Prasch, 2013; Suzuki et al., 2014). Plants grown in nature are exposed simultaneously to abiotic and biotic stresses. Abiotic stress was shown to alter the ability of plants resist/tolerate pathogens (Atkinson and Urwin, 2012; Prasch, 2013). Similarly, biotic stress was found to alter resistance/tolerance of hosts to abiotic stress (Xu et al., 2008; Atkinson and Urwin, 2012; Prasch, 2013). Therefore, responses of plants to single stress differ from those to multiple stresses (Atkinson and Urwin, 2012; Suzuki et al., 2014), and the simultaneous occurrence of multiple stresses can cause complex plant responses (Atkinson and Urwin, 2012; Prasch, 2013; Suzuki et al., 2014). Thus, better understanding of effects of combining abiotic with biotic stress is of great significance and would allow us to orientate agricultural management strategies to ensure sustainable development of agricultural production.

Grapevine (Vitis vinifera) is an economically important fruit crop worldwide. Virus disease and drought stress are the two key factors limiting high yield and quality production of grapevine (Martelli, 2012). Co-occurrence of drought and virus infection is common in many of grapevine-growing regions. However, most of the previous studies on the said issues addressed single stress, while the co-stress by virus and drought has been far less studied.

The objective of the present study was, therefore, to study responses of grapevines (Vitis vinifera) to Grapevine leafrollassociated virus-3 (GLRaV-3) and PEG-induced drought stress using in vitro culture system. The overall goal was to better understand the effect of abiotic and biotic stress, in single and particularly in combination, on growth, physiological metabolic processes and cell damage, thus providing valuable data upon which agricultural management strategies could be adjusted to allow more sustainable viticultural production.

\section{MATERIALS AND METHODS}

\section{Maintenance of In vitro Healthy and GLRaV-3 Infected Stock Plantlets and Establishment of PEG-Induced Drought Stress}

Vitis vinifera L. 'Cabernet Sauvignon', a major red wine cultivar grown worldwide and susceptible to GLRaV-3, was used in this

Abbreviations: ABA, abscisic acid; BM, basal medium; CAT, catalase; DAB, 3, 3'-diaminobenzidine; DW, dry weight; EL, electrolytic leakage; FW, fresh weight; GLRaV-3, Grapevine leafroll-associated virus-3; IAA, indoleactic acid; MDA, Methane Dicarboxylic Aldehyde; MS, Murashige and Skoog medium; NBT, nitroblue tetrazolium; PCD, Programmed cell death; PEG, polyethylene glycol; POD, peroxidase; ROS, Reactive oxygen species; SOD, superoxide dismutase. study. In vitro shoots suspected of GLRaV-3 infection were established in vitro, according to Cui et al. (2015). After 6 months of in vitro establishment, the suspected shoots were screened again by RT-PCR for their virus status including GVA, GVB, GRSPaV, GFkV, GFLV, and ArMV, which are among the grapevine viruses reported in China (Ren et al., 2013). Samples showing a positive response only to GLRaV-3 were maintained and others discarded. The GLRaV-3 infected shoots (scions) were micrografted on to the healthy in vitro shoots (rootstocks). Micrografts developed into plantlets after 3 months of micrografting. GLRaV-3 was confirmed by RT-PCR in the micrografted rootstocks (Cui et al., 2015) and shoot segments were excised from the virus-infected rootstocks were proliferated to establish the diseased in vitro stock shoots. Thus, the healthy and diseased in vitro stock shoots were produced from the same mother plants. Both the healthy and virus-infected the cultures were maintained on a basal medium (BM) containing halfstrength Murashige and Skoog (1962) medium (MS) with $30 \mathrm{~g}$ $\mathrm{1}^{-1}$ sucrose and $7 \mathrm{~g} \mathrm{l}^{-1}$ agar. The $\mathrm{pH}$ of the medium was adjusted to 5.8 prior to autoclaving at $121^{\circ} \mathrm{C}$ for $20 \mathrm{~min}$. The cultures were maintained at a constant temperature of $24 \pm 2^{\circ} \mathrm{C}$ under a 16 -h photoperiod with a light intensity of $50 \mu \mathrm{mol} \mathrm{s} \mathrm{s}^{-1} \mathrm{~m}^{-2}$ provided by cool-white fluorescent tubes. Subculture was done once every 6 weeks.

Shoot segments $(1.5-2.0 \mathrm{~cm}$ in length) with 2 fully-opened leaves were excised from in vitro 6-week-old healthy and virus-infected stock plantlets, respectively, and cultured on BM containing 0,2 , or $4 \%(\mathrm{w} / \mathrm{v})$ of polyethylene glycol (PEG) 8000, according to Cui et al. (2015), under the same cultural conditions as used for in vitro stock plantlets. Water potentials of medium containing 2 and 4\% PEG were $-2.4 \mathrm{MPa}$ and -2.7 $\mathrm{MPa}$, respectively, as calculated by Michel (1983). Unless stated otherwise, samples were taken after 4 weeks of culture and used for the following experiments.

\section{Vegetative Growth of In vitro GLRaV-3 Infected Plantlets with and without Drought Stress}

Vegetative growth including time required for axillary bud elongation, shoot length, number of roots, length of the longest root, and fresh weight (FW) and dry weight (DW) of shoots and roots were measured after 6 weeks of culture. Axillary bud elongation was defined when $\geq 50 \%$ of shoots showed bud elongation.

\section{Analysis of Total Soluble Protein}

Shoots with leaves of $(0.5 \mathrm{~g} \mathrm{FW})$ were extracted with $3 \mathrm{ml}$ of $50 \mathrm{mM}$ phosphate buffer ( $\mathrm{pH} 7.0)$, followed by centrifugation at $10,000 \mathrm{rpm}$ for $10 \mathrm{~min}$. The supernatant was collected and absorbance was recorded at $595 \mathrm{~nm}$ in a spectrophotometer (Thermo Multiskan MK3, USA) with bovine serum albumin (BSA) as a standard, according to Bradford (1976).

\section{Analysis of Free Proline}

Free proline content was determined according to the method of Bates et al. (1973). Shoots with leaves ( $0.5 \mathrm{~g} \mathrm{FW)} \mathrm{were}$ homogenized with $10 \mathrm{ml}$ of $3 \%(\mathrm{w} / \mathrm{v})$ sulfosalicylic acid. The 
homogenate was centrifuged at $3000 \mathrm{rpm}$ for $20 \mathrm{~min}$. The supernatant was treated with acid ninhydrin in boiling water for $1 \mathrm{~h}$. The reaction was terminated in a water bath at a room temperature for $10 \mathrm{~min}$. The reaction mixture was extracted with $4 \mathrm{ml}$ of toluene and vortexed for $15 \mathrm{~s}$. The absorbance was determined at $520 \mathrm{~nm}$ in a spectrophotometer (Thermo Multiskan MK3, USA) using L-proline as a standard.

\section{Analysis of Cell Membrane Damage (CMD) and Cell Death}

Roots $(0.5 \mathrm{~g} \mathrm{FW})$ were used for analysis of cell membrane damage (CMD) by measuring relative electrolytic leakage (EL), according to the method of Sullivan (1972). Cell death was detected by Evan's blue staining method (Gaff and Okong'O-Ogola, 1971). Samples were immersed in $0.1 \%$ Evan's blue solution for $30 \mathrm{~min}$, and then washed with distilled water for 3 times to stop the color reaction. Staining reaction was photographed using a digital camera (PowerShot G9, Canon, Japan).

\section{$\mathrm{O}_{2}^{--}$and $\mathrm{H}_{2} \mathrm{O}_{2}$ Localization In situ}

Fresh leaves were used for $\mathrm{O}_{2}^{--}$and $\mathrm{H}_{2} \mathrm{O}_{2}$ localization in situ, according to the method of Romero-Puertas et al. (2004), with some modifications. For $\mathrm{O}_{2}^{--}$localization, leaves were immersed in $0.1 \%$ solution of nitroblue tetrazolium (NBT) in $10 \mathrm{mM} \mathrm{K}$ phosphate buffer ( $\mathrm{pH} \mathrm{7.6)}$, vacuum-infiltrated for $30 \mathrm{~min}$ and illuminated for $2 \mathrm{~h}$, followed by bleaching in $95 \%$ boiling ethanol for $5 \mathrm{~min}$. For $\mathrm{H}_{2} \mathrm{O}_{2}$ localization, leaves were immersed in a $0.1 \%$ filtered solution of $3,3^{\prime}$-diaminobenzidine (DAB) in $10 \mathrm{mM}$ MES buffer ( $\mathrm{pH}$ ), vacuum-infiltrated for $30 \mathrm{~min}$ and then incubated at room temperature for $4 \mathrm{~h}$ in the dark, followed by bleached in 95\% boiling ethanol for $5 \mathrm{~min}$. Photographs were captured by a digital camera (PowerShot G9, Canon, Japan).

\section{Analysis of Antioxidant Enzyme Activities}

The activities of superoxide dismutase (SOD), peroxidase (POD), catalase (CAT) were measured, as described by Li et al. (2011). Fresh leaves $(0.5 \mathrm{~g} \mathrm{FW})$ were harvested from 2 -week-old plantlets grown at 0 and $4 \%$ PEG, ground in liquid nitrogen and extracted with following extraction media: $100 \mathrm{mM}$ potassium phosphate buffer ( $\mathrm{pH} 7.8$ ) containing $0.1 \mathrm{mM}$ EDTA, 1\% (w/v) PVP and $0.1 \%(\mathrm{v} / \mathrm{v})$ Triton $\mathrm{x} 100$. The extracts were centrifuged at 10,000 $\mathrm{rpm}$ for $15 \mathrm{~min}$ at $4^{\circ} \mathrm{C}$. The supernatants were collected and used for the enzyme activity assays.

The SOD activity was determined by measuring its ability to inhibit photochemical reduction of nitrobluetetrazolium (NBT). The reaction mixture $(3 \mathrm{ml})$ contained $0.3 \mathrm{ml}$ each of $20 \mu \mathrm{M}$ riboflavin, $150 \mathrm{mM}$ l-methionine, $600 \mu \mathrm{M}$ NBT and $0.1 \mathrm{ml}$ extract, and performed under irradiance of $170 \mu \mathrm{mol}$ photons $\mathrm{m}^{-2} \mathrm{~s}^{-1}$ provided by white fluorescent lamps. The absorbance was determined at $560 \mathrm{~nm}$. The extract volume causing 50\% inhibition of NBT reduction was taken as one unit of activity. The POD activity was measured in the reaction mixture $(3 \mathrm{ml})$ containing $50 \mathrm{mM}$ phosphate buffer ( $\mathrm{pH} 7.0$ ), $0.2 \mathrm{mM}$ guaiacol, $10 \mathrm{mM} \mathrm{H} \mathrm{O}_{2}$. The reaction was initiated by adding $200 \mu \mathrm{l}$ of enzyme extract to the reaction mixture. The oxidation of guaiacol was measured upon an increase in absorbance at $470 \mathrm{~nm}$ for $1 \mathrm{~min}$. The CAT activity was determined by directly measuring the decomposition of $\mathrm{H}_{2} \mathrm{O}_{2}$ at $240 \mathrm{~nm}$ in a spectrophotometer (Thermo Multiskan MK3, USA). The reaction mixture (3 ml) contained 0.05 M Na phosphate buffer ( $\mathrm{pH}$ 7.0) supplemented with $1 \mathrm{mM}$ EDTA, $\mathrm{H}_{2} \mathrm{O}_{2}(3 \%)$ and $100 \mu \mathrm{l}$ of enzyme extract.

\section{Analysis of Methane Dicarboxylic Aldehyde (MDA)}

The MDA content was determined according to $\mathrm{Li}$ et al. (2011). Briefly, leaves (1.0 g FW) taken from 2-week-old plantlets grown at 0 and 4\% PEG were homogenized in $10 \mathrm{ml}$ of $10 \%$ trichloroacetic acid, followed by centrifugation at $10000 \mathrm{rpmg}$ for $10 \mathrm{~min}$. After then, $2 \mathrm{ml}$ of $0.6 \%$ thiobarbituric acid in $10 \%$ trichloroacetic acid were added to $2 \mathrm{ml}$ of the supernatant. The mixture was heated in boiling water for $15 \mathrm{~min}$, and then quickly cooled in an ice bath. After centrifugation at $10,000 \mathrm{rpm}$ for 10 $\mathrm{min}$, the absorbance of the supernatant was recorded at $450 \mathrm{~nm}$, $532 \mathrm{~nm}$ and $600 \mathrm{~nm}$ in a spectrophotometer (Thermo Multiskan MK3, USA). The MDA concentration was calculated using the following formula: 6.45(OD 532-OD 600)-0.56OD450.

\section{Analysis of Endogenous Hormones}

Contents of endogenous ABA and IAA were analyzed in the in vitro plantlets grown at 0 and $4 \%$ PEG. Shoots with leaves were taken from 1-week-old plantlets and divided into two groups. One group was used for analysis of $\mathrm{ABA}$ and IAA, and the other for measurement of transcription level of ABA and IAA biosynthetic genes, as described below. Samples were frozen in liquid nitrogen and stored at $-80^{\circ} \mathrm{C}$ until usage. Abscisic acid (ABA) and indoleactic acid (IAA) were provided by Sigma (St. Louis, MO, USA). At the beginning of extraction, $1000 \mathrm{~Bq}$ of each $\mathrm{ABA}$ and IAA, accordingly, were added to monitor the losses during purification. The extraction and purification of ABA and IAA were conducted, according to by Dobrev et al. (2005). The purified extract solution was transferred into 2-ml centrifuge tubes containing $0.3 \mathrm{~g}$ polyvinylpolypyrolidone (PVPP) and then kept at $-20^{\circ} \mathrm{C}$ for the measurements of $\mathrm{ABA}$ and IAA in water breeze HPLC system (Waters 2489 UV/Visible Detector), using wavelength at $254 \mathrm{~nm}$, velocity at $0.7 \mathrm{ml} \mathrm{min}^{-1}$ and sample quantity of $10 \mu \mathrm{m}$ and column temperature at $30^{\circ} \mathrm{C}$. The dried fraction containing $\mathrm{ABA}$ and IAA were, respectively, injected into the HPLC system for measurements, as described by Li et al. (2013).

\section{Analysis of Transcription Level of ABA and IAA Biosynthetic Genes}

The transcription levels of several major genes responsible for biosynthesis of $\mathrm{ABA}$ and IAA were analyzed in the in vitro plantlets grown at 0 and $4 \%$ PEG at different time durations. RNA was isolated from shoots with leaves ( $1 \mathrm{~g} \mathrm{FW})$, as described by Davies and Robinson (1996). RNA quality was evaluated by optical density (OD) value (1.9-2.1) at 260/280 nm. After removal of DNA using DNA Eraser (Takara, Japan), cDNA was synthesized using the reagent kits (RR047A, Takara, Japan) according to the manufacture's instructions. All the candidate primers and reference genes of ABA and IAA biosynthesis pathway were selected according to the existing studies (Table 1). The reagent kits (RR047A, Takara) were used for qPCR reaction 
TABLE 1 | Primers used for qRT-PCR analysis of ABA and IAA in in vitro plantlets of grape 'Cabernet Sauvignon'.

\begin{tabular}{|c|c|c|c|c|}
\hline $\begin{array}{l}\text { Primer } \\
\text { names }\end{array}$ & References & Sequence $5^{\prime}-3^{\prime}$ (forward/reverse) & PN40024 12X V1 ID* & Coordinates* \\
\hline VVNCED1 & Wheeler et al., 2009 & GAGACCCCAACTCTGGCAGG/ AAGGTGCCGTGGAATCCATAG & VIT_19s0093g00550 & chr19:17645348..17647649 \\
\hline VVNCED2 & Wheeler et al., 2009 & AGTTCCATACGGGTTCATGGG/ CCATITCCAAATCCAGGGTGT & VIT_10s0003g03750 & chr10:6374432..6376728 \\
\hline VVZEP & Wheeler et al., 2009 & TACCGGGTATIITGGGACA/ CTTCTTCATCCGTGGCAAGT & VIT_07s0031g00620 & chr7:16795707..16804559 \\
\hline VVTAR2 & Böttcher et al., 2013 & CAGCAATGAAGCATATTGAAGG/ GAGTGAGAGCACCAGGAAATG & VIT_17s0000g08990 & chr17:10559797..10565113 \\
\hline VVTAR3 & Böttcher et al., 2013 & CCCAAGATGACT TTGATATGCTG/ TGATCAACTGATTGTTGATTCCACT & VIT_18s0157g00090 & chr18:18858918..18864125 \\
\hline VvTAR4 & Böttcher et al., 2013 & CAGCCTCATCAAGACCCAAGAT/ TGACGGTTGATTTCATTCTTCG & VIT_18s0157g00170 & chr18:18980507..18985732 \\
\hline VVYUC1 & Böttcher et al., 2013 & CAGGAAACTGTCGCAATAGTGG/ CAAGAACTATGTTGGGTATTGAGAGG & VIT_07s0104g01250 & chr7:2276803..2279543 \\
\hline VVACTIN2 & Böttcher et al., 2011 & GCACCCTTCG CACGATATGA/ TGACGCAAGGCAAGGACTGA & VIT_04s0044g00580 & chr4:21427077..21431176 \\
\hline
\end{tabular}

*Means V1 annotations obtained from CRIBI (http://genomes.cribi.unipd.it/grape/) by a BLAST search of the gene sequence provided by NCBI (http://www.ncbi.nlm.nih.gov).

(IQ5, BIO-RAD, USA) in a $25 \mu$ l reaction mixture containing $12.5 \mu \mathrm{l}$ of $2 \times$ SYBR Green I Master Mix, $1 \mu \mathrm{l}$ of each primer $(0.4 \mu \mathrm{M}), 2 \mu \mathrm{l}$ of cDNA $(100 \mathrm{ng})$ and $8.5 \mu \mathrm{l}$ of RNase-free water according to the kits instructions. The following program was used: an initial denaturation step at $94^{\circ} \mathrm{C}$ for $30 \mathrm{~s}, 45$ cycles at $94^{\circ} \mathrm{C}$ for $10 \mathrm{~s}, 56^{\circ} \mathrm{C}$ for $10 \mathrm{~s}$ and $72^{\circ} \mathrm{C}$ for $30 \mathrm{~s}$. A melting curve analysis was carried out over the range $65-97^{\circ} \mathrm{C}$ to verify the specificity of amplicons. Two controls (no-RT and no-template) were included in the designs. Transcript levels of each gene were normalized according to the reference gene, using the 2-(-Delta Delta C (T) method (Livak and Schmittgen, 2001).

\section{Experimental Design and Data Analysis}

Since some of the leaves at the basal part of the diseased shoots showed GLRaV-3 symptoms when grown under PEG-induced stress (Cui et al., 2015), symptomless leaves were used in all experiments. The experiments determining effects of virus and drought stress on vegetative growth of in vitro plantlets were designed as a completely randomized design. Ten samples were included in each of three replicates and the whole experiment was repeated at least twice. In all experiments measuring contents of total soluble protein, proline and MDA, activities of SOD, POD and CAT, endogenous hormones and transcript levels of $\mathrm{ABA}$ and IAA biosynthetic genes, each treatment contained five biological replicates and repeated three times in each experiment. Statistical analysis of the data was performed with the SPSS-19 for Windows statistics software package. Significant differences among means were calculated by the least significant difference (LSD) at $P \leq 0.05$. Two-way ANOVA, including GLRaV-3 infection and drought as factors, was performed to analyze the combined effects of these two factors on some selected parameters. Two-way MANOVA was performed for the vegetative growth. Significant differences were analyzed at $P \leq 0.05$ and $P \leq 0.01$, respectively.

\section{RESULTS}

\section{Vegetative Growth and Root Formation}

Without PEG stress, time duration required for axillary bud elongation was much shorter in the healthy shoots ( 4.5 days) than in GLRaV-3 infected ones (6.1 days; Figure 1A). No significant differences were found in this parameter in the healthy shoots grown at $0 \%$ and $2 \%$ PEG, but PEG at $4 \%$ considerably delayed the time duration for axillary bud elongation (5.8 days). A similar pattern in axillary bud elongation was found in the diseased shoots grown at $2-4 \%$ PEG, but the negative effect was much stronger (Figure 1A). Shoot length was similar between the healthy and diseased shoots without PEG stress (Figure 1B). In the healthy shoots, shoot length markedly decreased as PEG concentrations increased from 0 to $4 \%$ (Figure 1B). This inhibitory effect exerted by PEG stress was much stronger on the infected shoots than on the healthy shoots (Figure 1B). When grown at $0 \%$ PEG, the healthy and virus infected shoots produced a similar number of roots (Figure 1C). Number of roots significantly decreased in the healthy shoots when grown at 2-4\% PEG (Figure 1C). Negative effects of PEG concentrations on the number of roots were much pronounced in the infected shoots than in the healthy ones (Figure 1C). The healthy shoots without PEG stress produced greater length of the longest roots than the virus infected ones (Figure 1D). Length of the longest roots was similar in the healthy shoots grown at 0 and $2 \%$ PEG (Figure 1D), but 4\% PEG resulted in much shorter length of the longest roots (Figure 1D). Co-stress by the virus and $4 \%$ PEG resulted in the shortest length of roots (Figure 1D). Without PEG stress, fresh weight (FW) of shoots was significantly greater in the healthy shoots than that of the virus infected ones (Figure 1E), and markedly reduced in the healthy shoots as PEG concentrations increased from 0 to $4 \%$. Influences exerted by costress of the virus and drought on FW of roots were similar to those of FW of shoots (Figure 1F). Without PEG, the dry weight (DW) of the healthy shoots was greater than that of the virus infected shoots (Figure 1G), and it decreased when grown at 2$4 \%$ PEG. The DW of the infected shoots also decreased as PEG concentrations increased from 2 to $4 \%$. There was no significant difference in DW of roots between the healthy and diseased shoots without PEG stress (Figure 1H). The DW of roots in both the healthy and infected shoots considerably reduced as PEG concentrations elevated from 0 to $2-4 \%$ (Figure $\mathbf{1 H}$ ). Twoway MANOVA of all data on vegetative growth showed that single GLRaV-3 infection and PEG-induced drought, singly, and GLRaV-3 in combination with PEG all had significantly $(P \leq 0.01)$ negative effects on vegetative growth (Table 2$)$. 

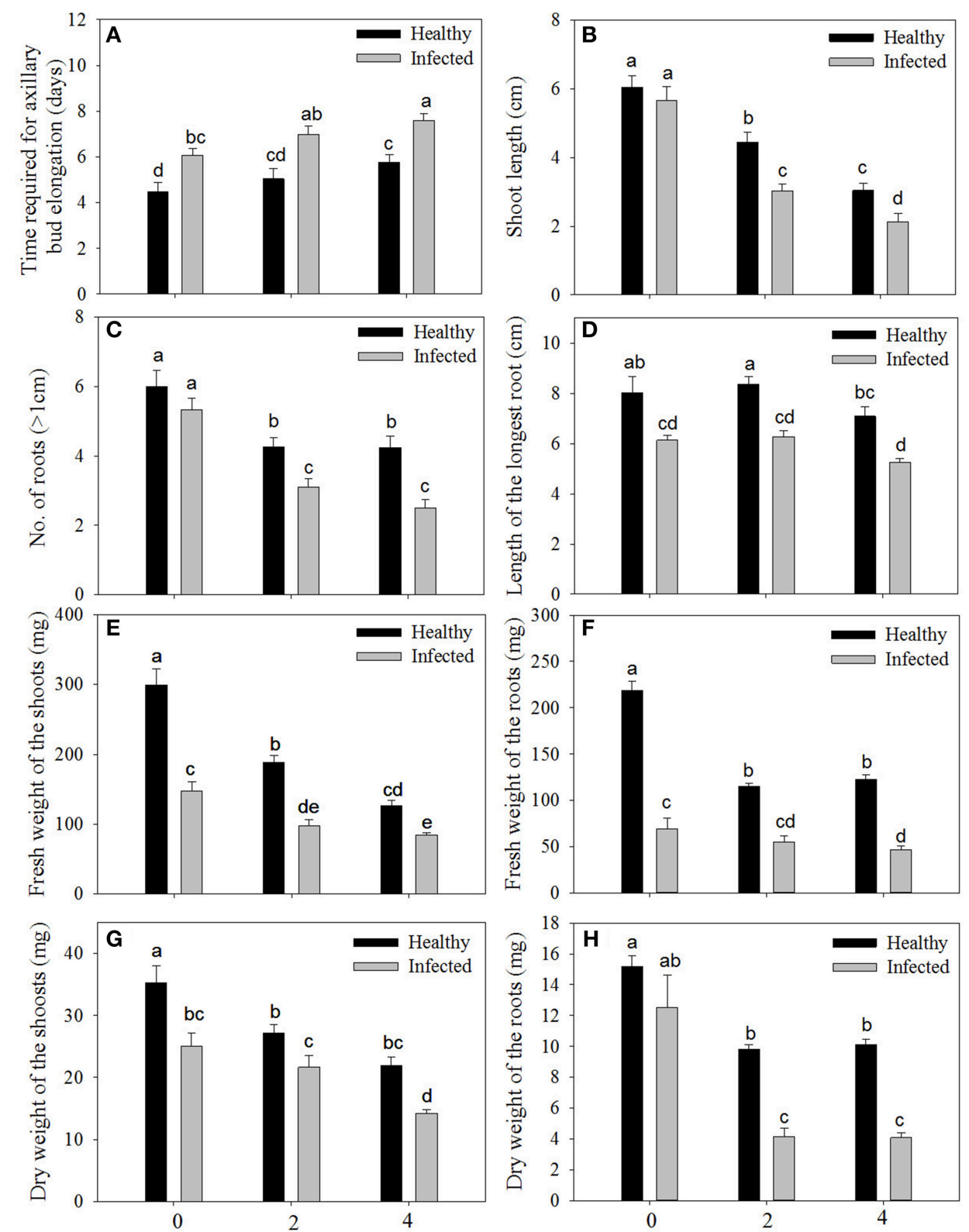

PEG concentrations (\%)

FIGURE 1 | Effects of GLRaV-3 infection and drought stress on shoot growth and root formation of in vitro plantlets of grape 'Cabernet Sauvignon'. (A) Time required for axillary bud elongation. (B) Shoot length. (C) Number of roots. (D) Length of the longest root. (E) Fresh weight of the shoots. (F) Fresh weight of the roots. (G) Dry weight of the shoots. (H) Dry weight of the roots. Data were presented as means \pm SE and with different letters within the same parameter are significantly different at $P \leq 0.05$.

\section{Content of Total Soluble Protein and Free}

\section{Proline}

A significant difference was found in content of total soluble protein between the healthy and virus-infected shoots without PEG stress (Figure 2A). In the healthy shoots, marked reductions were found in content of total soluble protein only when grown at $4 \%$ PEG. In the infected shoots, PEG concentrations at $2-4 \%$ caused considerable decreases in contents of total soluble protein (Figure 2A). Content of free proline was similar in the healthy and diseased shoots without PEG stress (Figure 2B). In the healthy shoots, PEG at 2-4\% significantly increased accumulations of free proline (Figure 2B). Levels of free proline considerably increased in the virus-infected shoots as PEG concentrations increased from 0 to $4 \%$ (Figure 2B). Two-way ANOVA showed that virus infection and PEG stress, and virus infection in combination with PEG stress had significant negative 
TABLE 2 | Two-way MANOVA of effects of GLRaV-3 and PEG-induced drought, and their combing effects on all variables of vegetative growth of in vitro plantlets of grape 'Cabernet Sauvignon'.

\begin{tabular}{lccc}
\hline Parameters & Wilk's Lambda & F & $\boldsymbol{p}$ \\
\hline Virus & 0.031 & 66.690 & $* *$ \\
Drought & 0.008 & 22.241 & $* *$ \\
Virus-drought & 0.003 & 37.855 & **
\end{tabular}

${ }^{\star *}$ Significant difference at $P \leq 0.01$.

effects on contents of both total soluble protein and free proline (Table 3).

\section{Cell Membrane Damage and Cell Death}

Relative electrolytic leakage (EL) was similar in the healthy and diseased shoots without any stress (Figure 2C). Stress by PEG concentrations at 2 and $4 \%$ produced increased EL comparing to $0 \%$ PEG in the healthy shoots. The similar pattern of EL was found in the diseased shoots grown under 2-4\% PEG concentrations, but the negative effect was much more obvious.

Blue color forms when dead cells are stained by Evan's blue solution. Without PEG stress, almost no blue color was seen in the healthy roots (Figure $\mathbf{3 A}$ ), but some light blue color was observed in GLRaV-3 infected roots (Figure 3B). Density and areas of blue color formation increased with increasing PEG concentrations from 2 to $4 \%$ in both the healthy (Figures 3C,E) and virus-infected roots (Figures 3D,F). The virus-infected roots had a much stronger blue color and larger areas than the healthy roots that were treated by the same concentrations of PEG. When grown at $4 \%$ PEG, almost the whole roots infected by GLRaV-3 became blue (Figure 3F).

\section{$\mathrm{O}_{2}^{--}$and $\mathrm{H}_{2} \mathrm{O}_{2}$ Localization In situ}

Production of $\mathrm{O}_{2}^{-}$in the leaves is visualized with NBT staining to give rise to dark blue spots. Without PEG stress, $\mathrm{O}_{2}^{-}$accumulation was hardly detected in the healthy leaves (Figure 4A), but it was easily seen in the diseased leaves (Figure 4B). In the healthy leaves, $\mathrm{O}_{2}^{--}$accumulation considerably increased with an increase in PEG concentrations from $2 \%$ (Figure $4 \mathrm{C}$ ) to $4 \%$ (Figure $4 \mathrm{E}$ ). A similar pattern was found in the diseased leaves, but staining density and stained areas were much stronger (Figure 4D) and larger (Figure 4F) than in the corresponding healthy samples. Production of $\mathrm{H}_{2} \mathrm{O}_{2}$ in the leaves is visualized with $\mathrm{DAB}$ staining to give rise to brown spots. Without PEG, $\mathrm{H}_{2} \mathrm{O}_{2}$ accumulation in the virusinfected leaves (Figure 5B) was stronger than that in the healthy leaves (Figure 5A). Although, PEG stress at 2-4\% markedly increased $\mathrm{H}_{2} \mathrm{O}_{2}$ accumulation in both the healthy and infected leaves, staining density and strained areas were much stronger and larger in the virus-infected leaves than in the healthy leaves that were stressed by the corresponding PEG concentrations (Figures 5C-F).

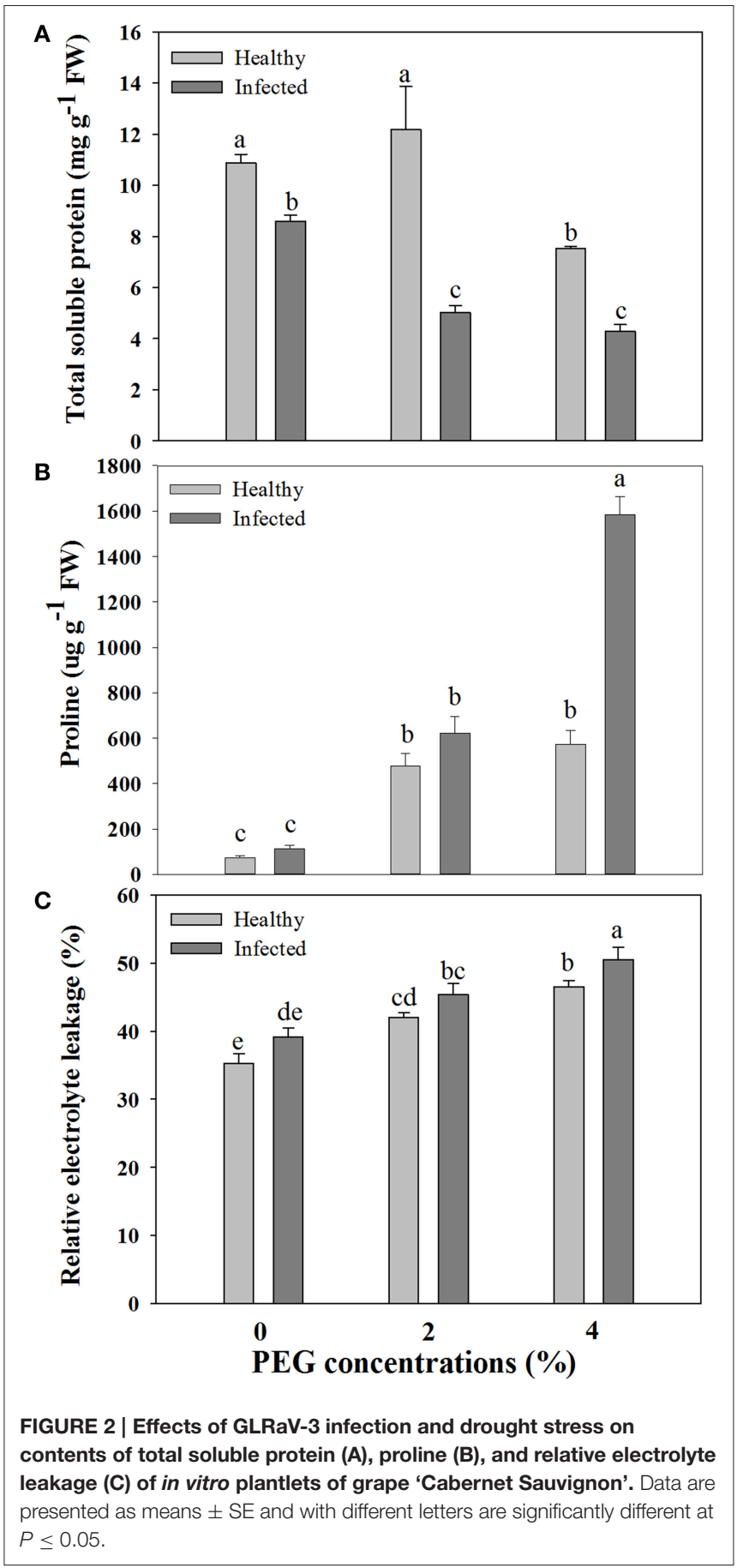

\section{Activities of Antioxidant Enzymes and Content of MDA}

Without PEG stress, no significant differences were found in the activities of SOD, POD, and CAT between the virus-infected and healthy plantlets (Figures 6A-C). For the healthy plantlets, 4\% $\mathrm{PEG}$ resulted in significant increases in the activities of SOD and POD, although not in CAT (Figures 6A-C). For the diseased plantlets, the activities of SOD, POD, and CAT significantly increased when stressed by PEG $4 \%$. No differences were found 
TABLE 3 | Two-way ANOVA of effects of GLRaV-3 and drought, and their combining effects on indexes of in vitro plantlets shoots of grape 'Cabernet Sauvignon'.

\begin{tabular}{|c|c|c|c|}
\hline Contents of Influenced indexes & Virus & Drought & Virus-Drought \\
\hline Total soluble protein & ** & ** & * \\
\hline Proline & ** & ** & ** \\
\hline SOD & ** & ** & * \\
\hline POD & ** & ** & ** \\
\hline CAT & ** & ** & ** \\
\hline MDA & ** & ** & *夫 \\
\hline ABA & ** & ** & ** \\
\hline IAA & ** & ** & ns \\
\hline
\end{tabular}

**Significant difference with levels of $P \leq 0.01$; *Significant difference with levels of $P \leq$ 0.05; $n s=$ no significant difference.

in MDA contents between the healthy and diseased plantlets without PEG stress (Figure 6D). MDA contents were found much higher both in the healthy and the diseased plantlets grown at 4\% PEG, (Figure 6D). Two-way ANOVA showed that single stress by either the virus or PEG significantly $(P \leq 0.01)$ changed the activities of SOD, POD, and CAT, and increased MDA content (Table 3). Co-stress by the virus and PEG had significantly $(P \leq$ $0.01)$ negative effects on those of POD, CAT and MDA, as well as on SOD $(P \leq 0.05)$ (Table 3$)$.

\section{Contents of ABA and IAA, and Expression Levels of ABA and IAA Biosynthetic Genes}

Without PEG stress, virus infection caused significant $(P \leq$ $0.05)$ increase and decrease in the content of ABA and IAA (Figures 7A,B), respectively. For the healthy plantlets, the content of ABA was significantly higher, while that of IAA was much lower, in the plantlets grown at 4\% PEG than at $0 \%$ PEG (Figures 7A,B). Similar patterns of ABA and IAA levels were found in the virus-infected plantlets grown at 0 and $4 \%$ PEG (Figures 7A,B). Two-way ANOVA showed that PEG stress or the virus infection and their co-stress all significantly $(P \leq 0.01)$ increased $\mathrm{ABA}$ content; the virus infection or drought stress significantly $(P \leq 0.01)$ decreased IAA level, but there was no interaction between them on IAA level (Table 3).

For ABA biosynthesis genes, without PEG stress, expression levels of NCED1 were relatively stable in the healthy plantlets during 1 week of culture, and peaked at $96 \mathrm{~h}$ of culture and then reduced in the virus infected plantlets (Figure 8A). Patterns of expression levels of NCED2 and ZEP were similar to those of NCED1 in the healthy plantlets (Figures $\mathbf{8 B}, \mathbf{C}$ ). In the diseased plantlets, expression levels of NCED2 started to increase at 48 $\mathrm{h}$ of culture and the increased levels maintained up to 1 week of culture (Figure 8B). Expression levels of ZEP were hardly detected until $48 \mathrm{~h}$ of culture, and relatively increased during $96 \mathrm{~h}$ and 1 week of culture (Figure 8C). PEG stress markedly induced expression levels of NCED1, NCED2, and ZE in both the healthy and diseased plantlets (Figures 8A-C). The highest expression levels appeared for NCED1 between 48 to $96 \mathrm{~h}$ in both the healthy and diseased plantlets (Figure 8A), for NCED2 at 48 and $96 \mathrm{~h}$ in the infected and healthy plantlets, respectively
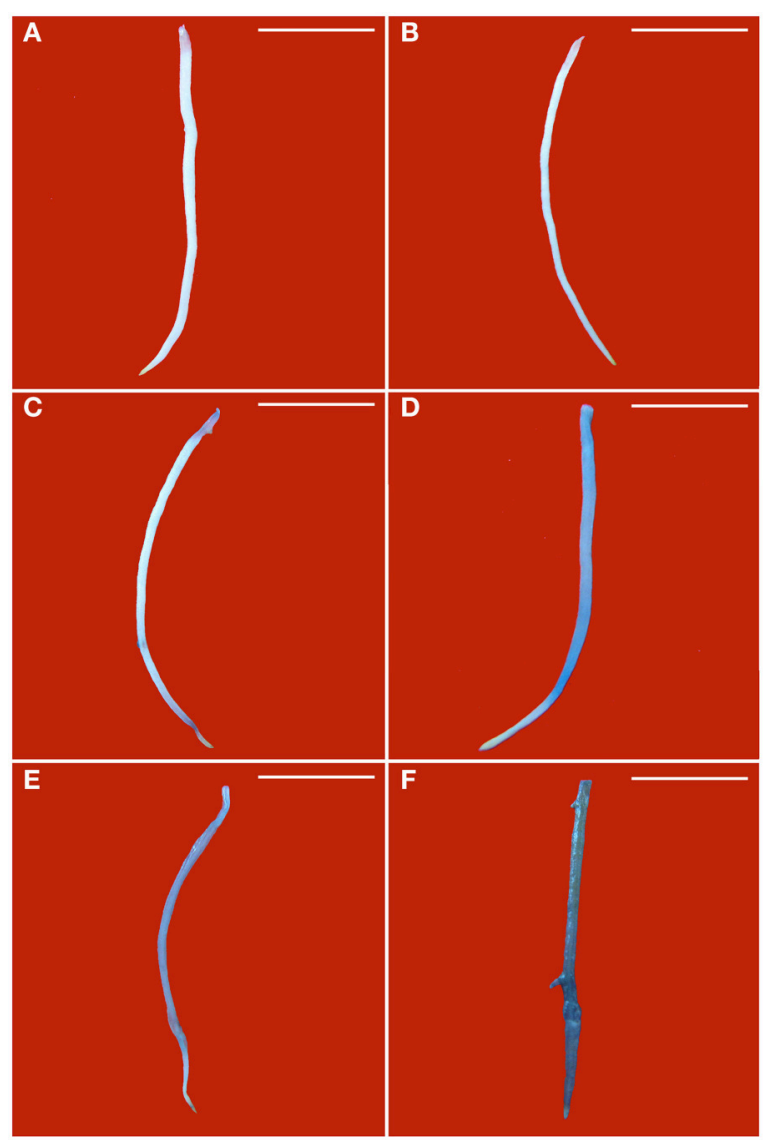

FIGURE 3 | Histochemical detection of cell death in roots of in vitro plantlets of grape 'Cabernet Sauvignon'. Cell death in the roots was revealed by the blue precipitates produced by staining with Evan's blue. Roots of the healthy shoots cultured at 0\% (A), 2\% (C), and 4\% PEG (E). Roots of GLRaV-3-infected shoots cultured at 0\% (B), 2\% (D), and 4\% PEG (F), Bar scale $=1 \mathrm{~cm}$.

(Figure 8B), for ZEP at $96 \mathrm{~h}$ in the two types of plantlets (Figure 8C). For IAA biosynthesis genes, without PEG stress, higher expression levels of TAR2, TAR3, TAR4, and YUC1 were detected in the healthy than in the diseased plantlets during the whole culture time durations (Figures 9A-D). Expression levels of TAR2, TAR3, and TAR4 started to increase at $24 \mathrm{~h}$, peaked at $96 \mathrm{~h}$ of culture and then decreased, while those of YUC1 peaked at $24 \mathrm{~h}$ and gradually decreased during $24 \mathrm{~h}$ to 1 weeks of culture (Figure 9D). PEG stress consistently reduced the expression levels of all the four genes in both the healthy and diseased plantlets during the whole culture durations, with more obviously reduced levels found in the diseased plantlets (Figures 9A-D).

\section{DISCUSSION}

Although, in vitro culture conditions largely differ from the field environments and responses of in vitro cultures to abiotic or biotic stress may differ from those of the field-grown plants in some cases (Suzuki et al., 2014), the former has been widely used 

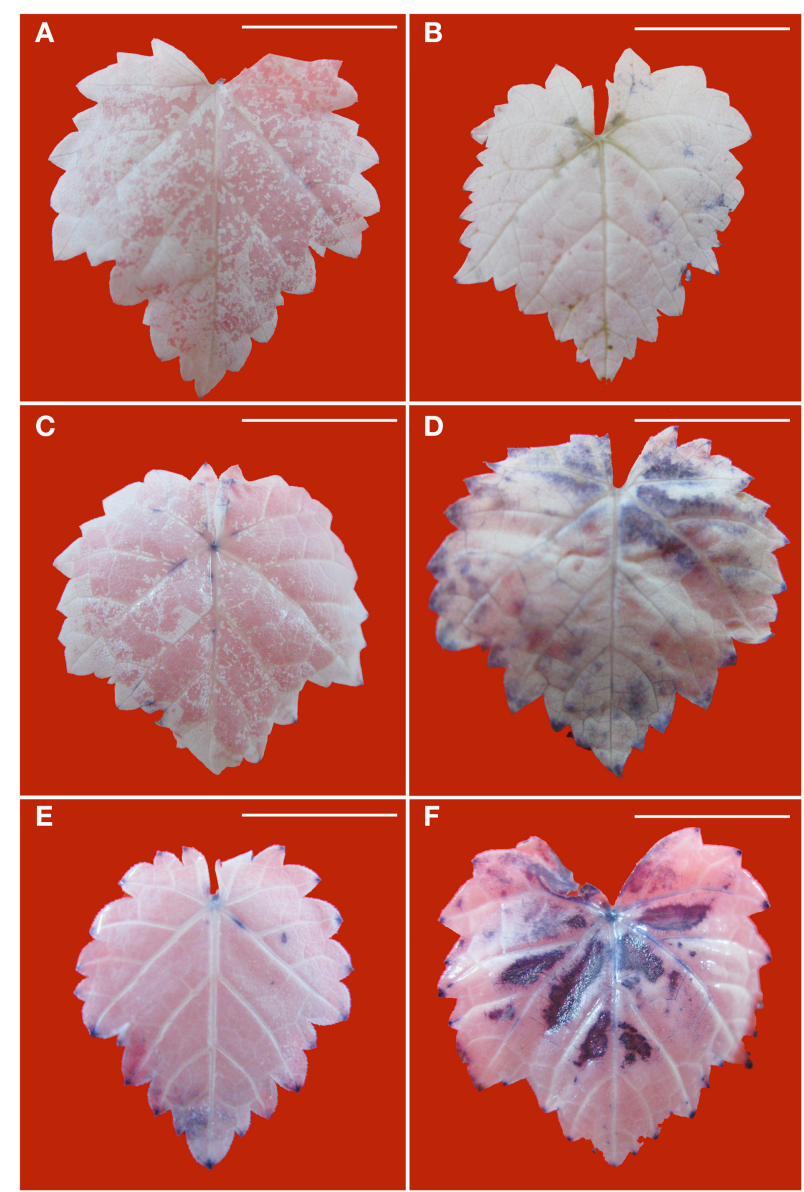

FIGURE 4 | Histochemical detection of $\mathrm{O}_{2}^{--}$in leaves of in vitro plantlets of grape 'Cabernet Sauvignon'. Deposits of $\mathrm{O}_{2}^{\cdot-}$ were revealed by the blue formazan precipitates produced by staining with NBT. Leaves of the healthy in vitro shoots cultured at 0\% (A), 2\% (C), and 4\% PEG (E). Leaves of GLRaV-3-infected shoots cultured at 0\% (B), 2\% (D), and 4\% PEG (F). Bar scale $=1 \mathrm{~cm}$.

for studies on the said subjects (Watanabe et al., 2000; Khristov et al., 2001; Christov et al., 2007; Lu et al., 2007; Lokhande et al., 2010, 2011; Faraloni et al., 2011; Li et al., 2013; Marković et al., 2014; Cui et al., 2015), mainly due to its advantages that can avoid other variables such as light, temperature and nutrients, and by attacks of other pathogens facing in the field, in addition to its effects of efficient, rapid and low cost, thus facilitating studies of 'pure' biotic or abiotic stress (Watanabe et al., 2000; Khristov et al., 2001; Christov et al., 2007; Lokhande et al., 2010, 2011; Li et al., 2013; Cui et al., 2015). A recent study of Faraloni et al. (2011) found a high accordance between the in vitro and in vivo chlorophyll fluorescence measurements in monitoring changes in photosynthetic activity in response to drought stress.

Effects of single stress by either virus or drought on plant growth have been well-documented, but co-stress by pathogens like virus and drought to plants has been far less studied. Working on the several grapevine cultivars, Marković et al. (2014) found that the healthy in vitro-grown shoots had much better shoot growth than the GLRaV-3 or other virus infected
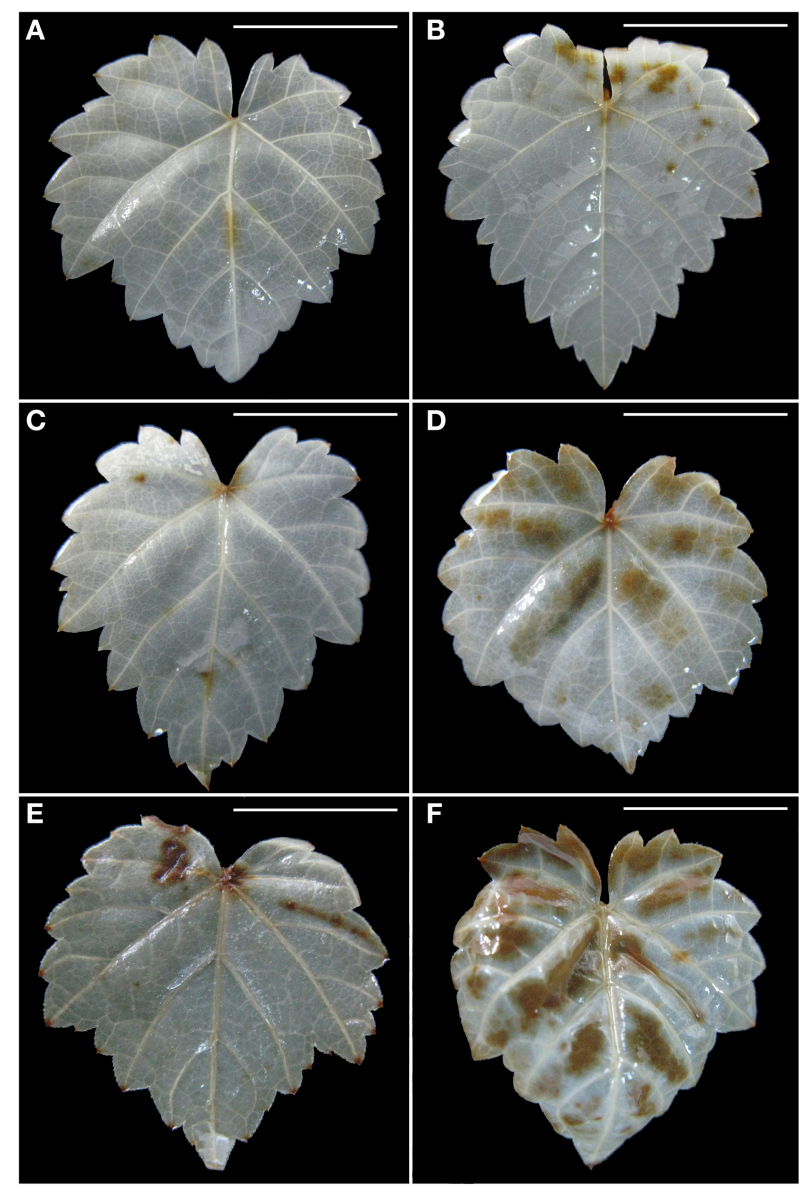

FIGURE 5 | Histochemical detection of $\mathrm{H}_{2} \mathrm{O}_{2}$ in leaves of in vitro plantlets of grape 'Cabernet Sauvignon'. $\mathrm{H}_{2} \mathrm{O}_{2}$ deposits were revealed by the brown precipitates produced by staining with DAB. Leaves of the healthy shoots cultured at $0 \%$ (A), 2\% (C), and 4\% PEG (E). Leaves of

LRaV-3-infected shoots cultured at 0\% (B), 2\% (D), and 4\% PEG (F). Bar scale $=1 \mathrm{~cm}$.

ones. Similar results have been reported in in vitro grapevine shoots infected by GLRaV-3 (Cui et al., 2015), Grapevine leafroll (Tanne et al., 1996), and Grapevine fanleaf virus (GFLV) (Abracheva et al., 1994). A number of examples of negative effects of virus infection on plant growth can be found in the publications of Watanabe et al. (2000), Li et al. (2013), and Cui et al. (2015). Reduced vegetative growth and slow rooting were observed in the in vitro grapevine shoots stressed by 2-6\% PEG (Dami and Hughes, 1997) and by $4 \%$ sorbitol or $2-4 \%$ mannitol (Tanne et al., 1996). Inhibitory effects exerted by drought or osmotic stress on vegetative growth were much stronger in the grapevine leafroll infected shoots than in the healthy ones (Chaves et al., 2007; Cui et al., 2015). All of these results were consistent with ours.

Virus infection or drought stress has been found to influence levels of soluble protein. An increased level of soluble protein was noted in grapevine infected with GFLV and GLRaV-3 (Sampol et al., 2003) or GLRV (Bertamini et al., 2004; Moutinho-Pereira et al., 2012), in banana infected with BBTV (Haq et al., 2012) 


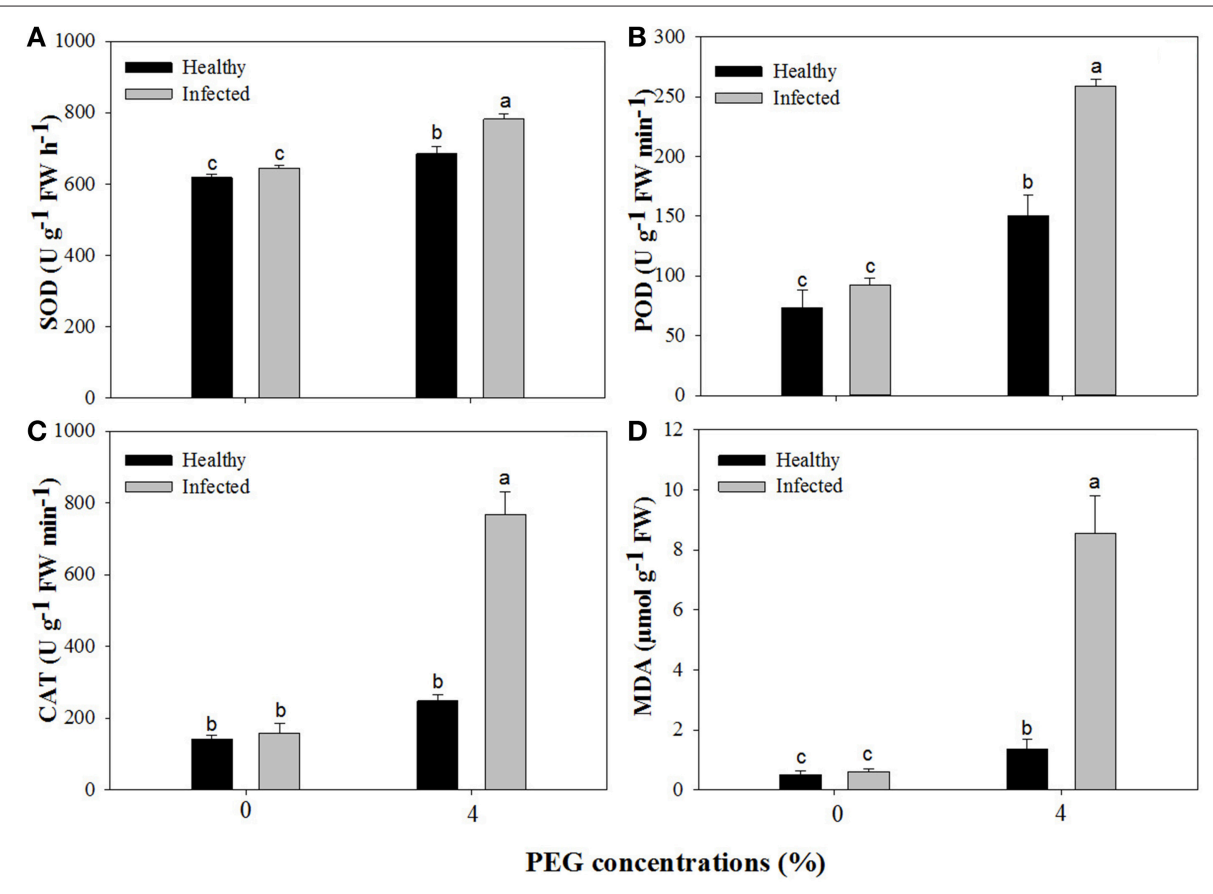

FIGURE 6 | Activities of superoxide dismutase (SOD, A), peroxidase (POD, B), catalase (CAT, C), and content of methane dicarboxylic aldehyde (MDA, D) of in vitro plantlets of grape 'Cabernet Sauvignon'. Data were presented as means \pm SE and with different letters within the same parameter are significantly different at $P \leq 0.05$.

and in potato infected with PLRV or PVY (Li et al., 2013). Similar results were also found in the present study. The decrease in synthesis of ribulose-1,5-bisphosphate (RuBP) carboxylase was found responsible for the marked reduction in the content of soluble proteins in the GLRV-infected samples (Bertamini et al., 2004). Decreased contents of total protein were observed in drought-stressed grapevine (Maroco et al., 2002) and other plants such as Zea mays (Hsiao, 1970), and Gossypium hirsutum (Parida et al., 2007). These data were again confirmed in our study. Drought stress caused marked changes in the protein synthesizing apparatus of plant tissue, thus reducing capacity for protein synthesis (Hsiao, 1970; Parida et al., 2007).

Our study found that drought stress and GLRaV-3 infection, singly or in combination, significantly increased proline contents. Increased proline contents by drought have been found in other plant species such as Populus euphratic (Watanabe et al., 2000), Eucalyptus camaldulensis (Woodward and Bennett, 2005) and Capsicum annuum (Fu et al., 2009), or by virus such as Zucchini yellow mosaic virus (ZYMV, Radwan et al., 2007). Proline accumulation generally is considered as a drought tolerance mechanism in plants (Chutia and Borah, 2012; Sun et al., 2013). Increased accumulation of proline was believed to be as an adaptive response to the stress, thus helping to maintain cell membrane integrity and protecting subcellular structures in drought-stressed plants (Chutia and Borah, 2012; Sun et al., 2013), and to activate a hypersensitive response (HR) to virus infection (Radwan et al., 2007).

Our results showed that GLRaV-3 infection did not significantly cause cell membrane damage and cell death, but drought, singly or in combination with the virus, markedly increased cell membrane damage and induced cell death, particularly when GLRaV-3 infected shoots were stressed by $4 \%$ PEG. Programmed cell death (PCD) has been widely observed in response of the plants to pathogenic infection (Greenberg and Yao, 2004). The HR in response to virus infection is a typical example of PCD (Greenberg and Yao, 2004). Increased cell membrane damage and cell death have been well established in the plants infected with various viruses such as Tobacco mosaic virus (TMV)-infected Nicotiana tabacum (del Pozo and Lam, 2003), Groundnut bud necrosis virus (GBNV)-infected Vigna unguiculata (Permar et al., 2014) and Soybean mosaic virus (SMV)-infected Glycine max (Zhang et al., 2014). The HR is typically induced upon virus infection as in interaction between host encoded resistance $(\mathrm{R})$ proteins and pathogen encoded avirulence proteins and functions to limit virus replication and thereby its eventual movement inside the host (Padder, 2014). Increased cell membrane damage and induced cell death by drought stress has also been found in other plants including Saccharum officinarum (Patade et al., 2008), Arabidopsis (Duan et al., 2010), and Cucumis sativus (Zhang et al., 2013). Drought stress-induced root cell death was suggested to be an adaptive response to the stress (Duan et al., 2010). Expression of BAX inhibitor-1 (AtBI1) increased in response to water stress in roots of Arabidopsis, indicating that AtBII and the endoplasmic reticulum (ER) response pathway reduced water stress-induced PCD (Duan et al., 2010).

MDA, a marker for lipid peroxidation, is frequently used as an indicator for measurement of cellular membrane damage (Masia, 

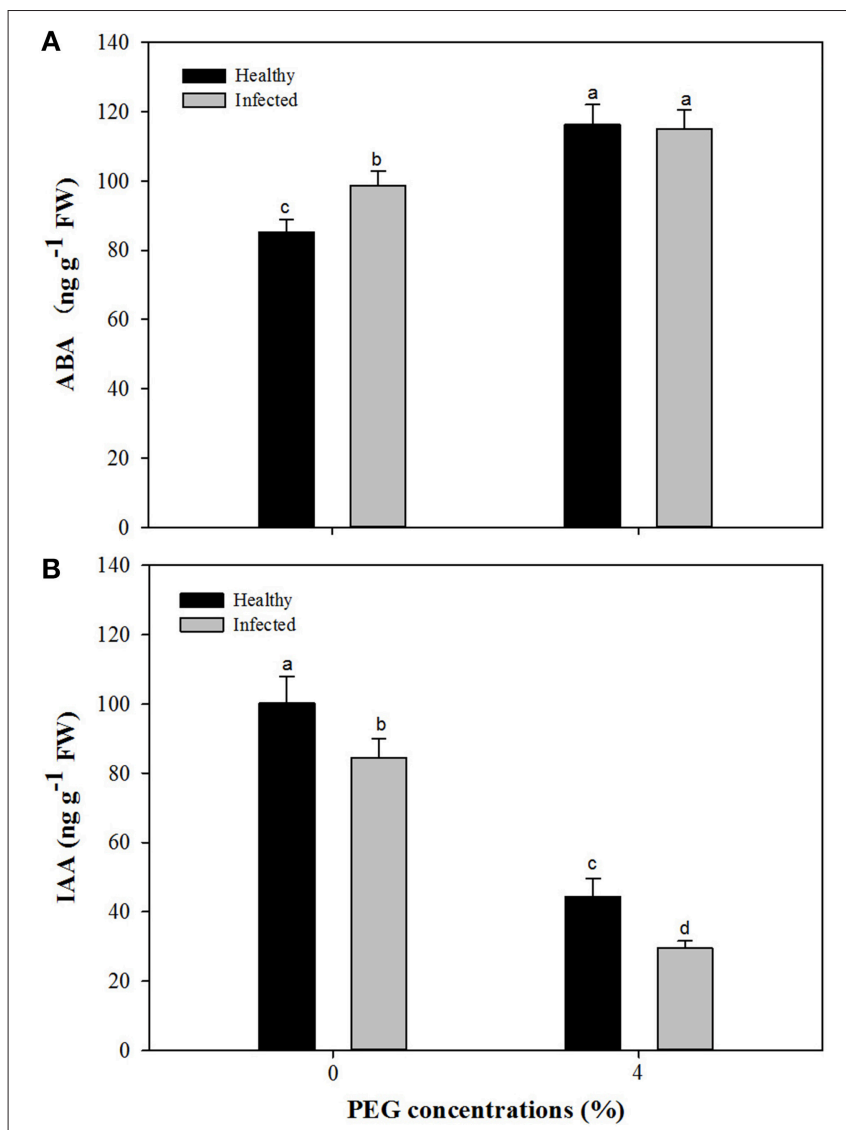

FIGURE 7 | Effects of GLRaV-3 infection and drought stress on content of ABA (A) and IAA (B) of in vitro plantlets of grape 'Cabernet

Sauvignon'. Data were presented as means \pm SE and with different letters within the same parameter are significantly different at $P \leq 0.05$.

2003). There have been many studies on drought-induced MDA, but data on virus-induced MDA have been quite limited. Huang et al. (2008) and Li et al. (2011) found the MDA level markedly increased in the plants under drought, indicating the occurrence of damage to cell membranes. These data were consistent with ours. In our study, virus infection did not cause significant accumulation of MDA, while 4\% PEG resulted in significant increase in MAD and the increased MAD was much obvious in plantlets co-stressed by drought and the virus, indicating extra injury to cell membranes by the interaction of drought stress and virus-infection.

Reactive oxygen species (ROS), particularly $\mathrm{O}_{2}^{--}$and $\mathrm{H}_{2} \mathrm{O}_{2}$, are subproducts responding to abiotic and biotic stress (Bolwell et al., 1999). A number of studies have shown that accumulation of $\mathrm{O}_{2}^{--}$and $\mathrm{H}_{2} \mathrm{O}_{2}$ considerably increased in plants infected by virus (Evans et al., 2006; Zhang et al., 2014) or stressed by drought (Duan et al., 2010; Gill and Tuteja, 2010; Sun et al., 2013; Noctor et al., 2014). In the present study, we found that stress by GLRaV-3 infection or drought increased the accumulation of $\mathrm{O}_{2}^{--}$and $\mathrm{H}_{2} \mathrm{O}_{2}$, and that accumulation was much greater when the in vitro shoots were stressed simultaneously by GLRaV-3 and PEG-induced drought. ROS has

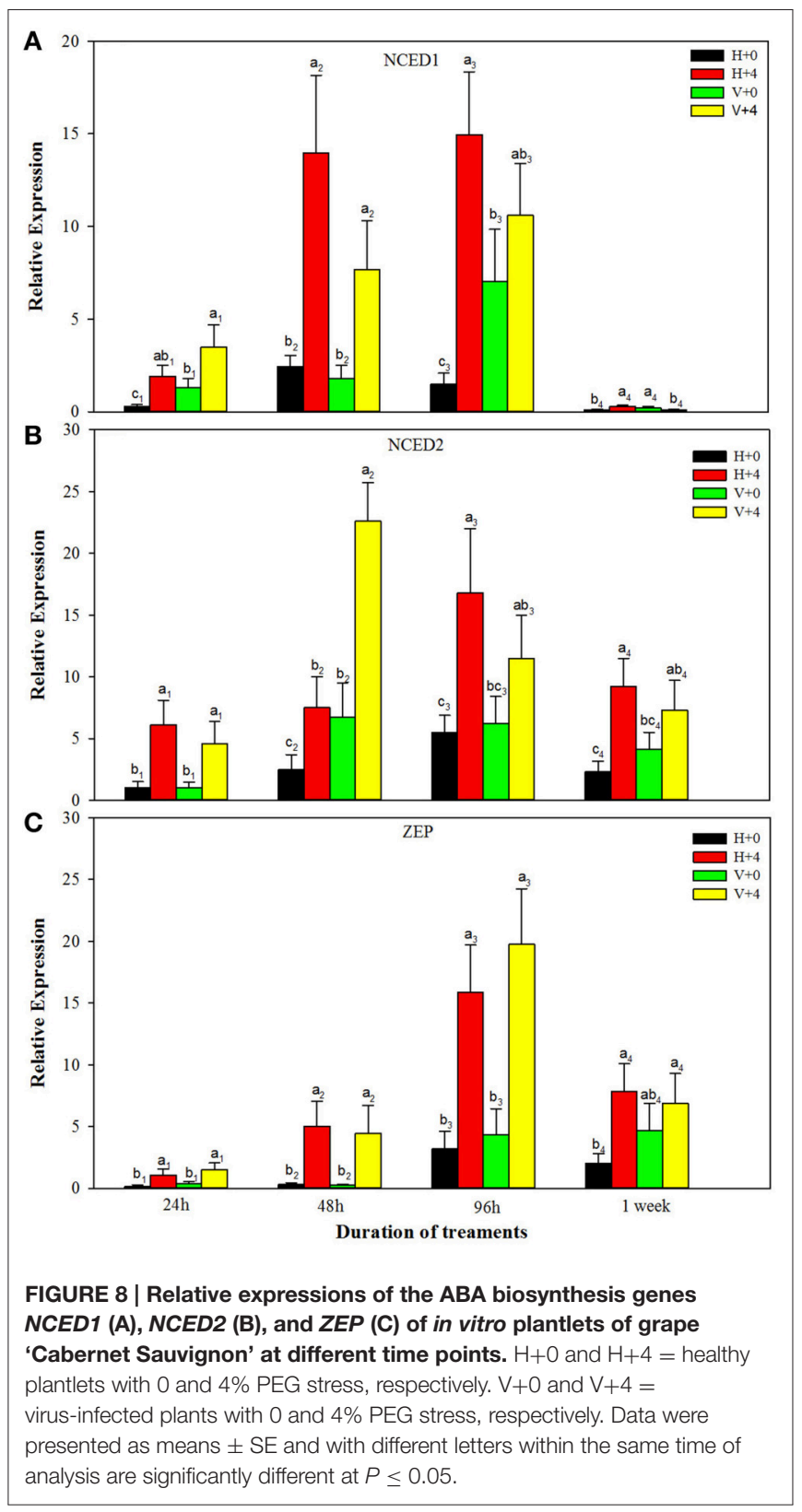

been shown to influence the expression of a number of genes and therefore manipulate various processes including growth, PCD, abiotic stress responses and pathogen defense (Gill and Tuteja, 2010). The production of ROS is the first response when plants are under biotic and abiotic stress (Gara et al., 2003; Evans et al., 2006), and as the stress continues, massive and prolonged ROS production, called an oxidative burst, occurs in the stressed cells (Gara et al., 2003). Accumulation of ROS in the virus-infected (Evans et al., 2006) or in abioticstressed plants may be associated with stress-induced oxidative bursts (Gara et al., 2003; Evans et al., 2006). Such oxidative bursts serve a number of protective functions activating defense responses of plants to biotic and abiotic stress (Gara et al., 2003). 

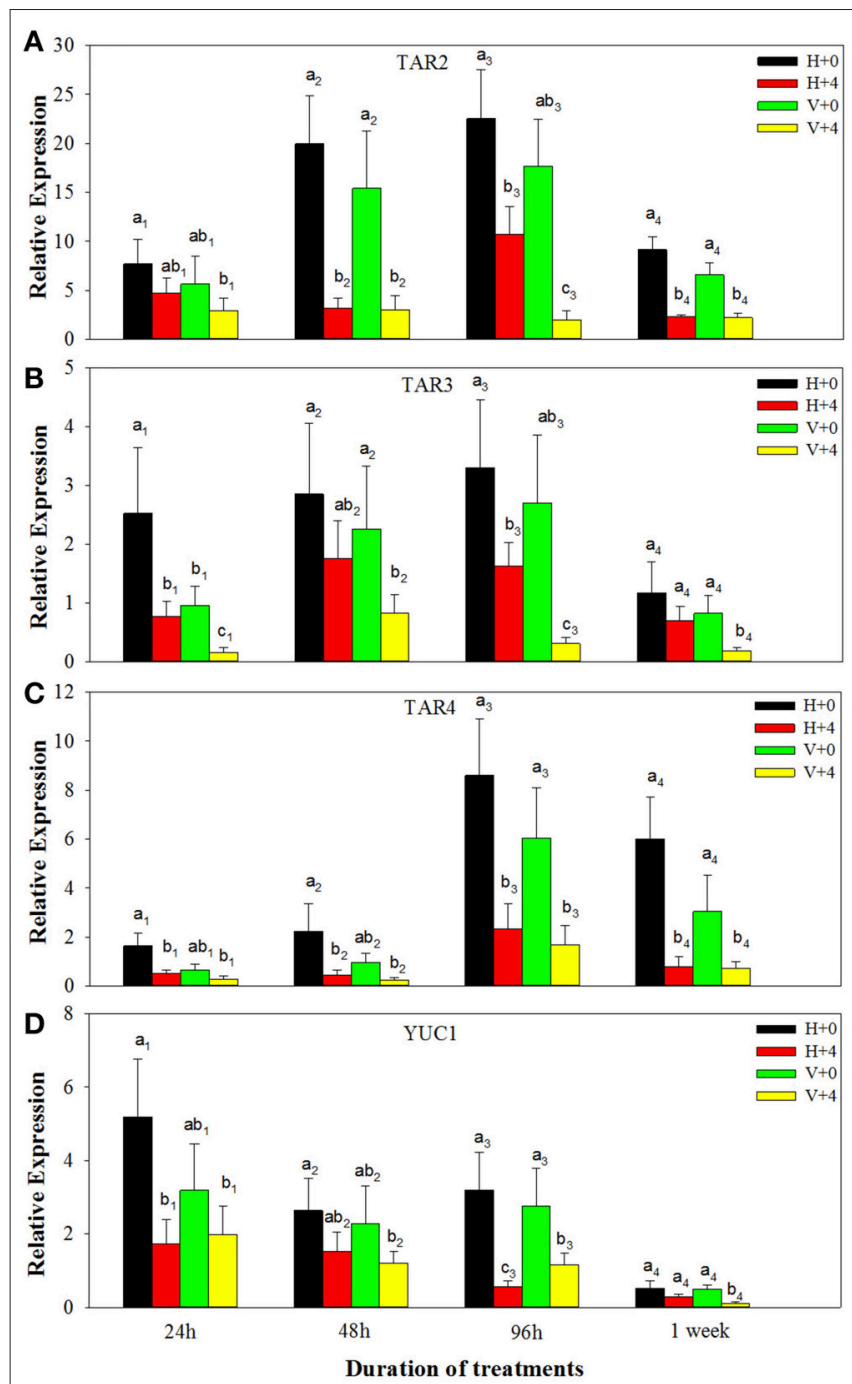

FIGURE 9 | Relative expressions of the IAA biosynthesis genes TAR2 (A), TAR3 (B), TAR4 (C), and YUC1 (D) of in vitro plantlets of grape 'Cabernet Sauvignon' at different time points. $\mathrm{H}+0$ and $\mathrm{H}+4=$ healthy plants with 0 and $4 \%$ PEG stress, respectively. $V+0$ and $V+4=$ virus-infected plants with 0 and 4\% PEG stress, respectively. Data were presented as means \pm SE and with different letters within the same time of analysis are significantly different at $P \leq 0.05$.

Numerous studies have demonstrated that plants are able to protect against abiotic stress (Gill and Tuteja, 2010; Li et al., 2011) or biotic stress (Gonçalves et al., 2013; Kyseláková et al., 2013) by increasing the activities of antioxidant enzymes such as SOD, CAT, and POD. In the present study, we found that drought stress significantly increased the activities of SOD, POD, and CAT in both the healthy and diseased plantlets, but single virus infection increased slightly the activity of antioxidant enzymes. The increased activities of three antioxidant enzymes were much higher in the plantlets co-stressed by the drought and virus, indicating a strong need for ROS removal. Transgenic plants that showed increase in CAT or POD or SOD activity exhibited enhanced tolerance to drought or pathogen resistance
(Gill and Tuteja, 2010). SOD was believed to be the first line of defense against the toxic effects of elevated levels of ROS caused by abiotic or biotic stress (Gill and Tuteja, 2010).

ABA generally inhibits plant growth and is thought to act as a messenger when plants were stressed by either drought or virus (Jameson and Clarke, 2002; Zhu, 2002). Increased accumulation in $\mathrm{ABA}$ in plants under drought stress has been well-documented (Zhu, 2002), whereas there existed only a few studies on virusinduced ABA and no studies on changes of ABA levels in plants co-stressed by drought and virus (Jameson and Clarke, 2002). The present study confirmed again grapevine in vitro plantlets responded to drought stress by increasing $A B A$ level, and found the level of ABA was higher in the GLRaV-3 infected plantlets than in the healthy ones. Similar results were also reported in plants infected with other viruses (Fraser and Whenham, 1989; Wang et al., 2011; Alazem et al., 2014). The increased levels of $\mathrm{ABA}$ were associated with up-regulation of ABA biosynthesis genes including NCED1, NCED2, and ZEP, which were the major genes for ABA biosynthesis in grapevine (Wheeler et al., 2009). These findings supported the speculation of Alazem et al. (2014) that the induction of $\mathrm{ABA}$ and up-regulation of the ABA biosynthesis genes may be common features of RNA virus infection. Increased levels of ABA in plants stressed by drought or infected with virus may eventually result in reduced growth, as found in the present study.

IAA can regulate diverse processes including growth, development and physiological metabolisms of plants (Kieffer et al., 2010; Swarup and Péret, 2012). Decreased IAA levels induced by drought stress have been reported in Brassica napus (Qaderi et al., 2006), Phaseolus vulgaris (Figueiredo et al., 2008), and Cotinus coggygria (Li et al., 2011). Reduced levels of IAA by virus infection were also found by Smith et al. (1968), Lockhart and Semancik (1970), Rao and Narasimham (1974), Rajagopal (1977), and Li et al. (2013). The results reported here were consistent with those mentioned above. The present study further found that co-stress by drought and virus resulted in much lower levels of IAA than single stress by either drought or virus, and down-regulation of expressions of IAA biosynthetic genes including TAR2, TAR3, TAR4, and YUC1 was associated with the decreased levels of IAA. Systemic virus infection was shown to influence the intercellular transport of the infected plants (Jameson and Clarke, 2002), which may prevent directional transport of auxin out of its source tissues, thus resulting in inhibition of shoot growth and root formation, as reported in the present study.

In conclusion, GLRaV-3 infection or drought stress reduced vegetative growth, affected physiological metabolisms, enhanced cell membrane damage and cell death, increased accumulation of $\mathrm{H}_{2} \mathrm{O}_{2}$ and $\mathrm{O}_{2}^{--}$, Co-stresses by virus infection and drought cause much more deleterious effects, than either single stress, on the studied parameters. Analysis of total soluble protein, free proline, activities of antioxidant enzymes, MDA, levels of ABA and IAA and expressions of their biosynthetic genes provide insights into better understanding of the adverse effects of virus infection and drought, in single and in combination, on the grapevine in vitro plantlets. Results obtained in the present study address 
use of virus-free plants and good irrigation toward achieving sustainable development of the grapevine.

\section{AUTHOR CONTRIBUTIONS}

ZC main work of all the experiments, data analysis and manuscript. WB phytohormone analysis and ROS gene expression analysis. $\mathrm{XH}$ the activity of the antioxidant enzymes YX design of the experiment and the financial support PL valuable discussion. AW the guide of the experiment and

\section{REFERENCES}

Abracheva, P., Rozenova, L., and Todorova, M. (1994). The influence of grapevine fanleaf virus and stem pitting on in vitro grapevine cultures. Vitis 33, $181-182$.

Alazem, M., Lin, K.-Y., and Lin, N. S. (2014). The abscisic acid pathway has multifaceted effects on the accumulation of Bamboo mosaic virus. Mol. Plant Microbe Interact. 27, 177-189. doi: 10.1094/MPMI-08-13-0216-R

Atkinson, N. J., and Urwin, P. E. (2012). The interaction of plant biotic and abiotic stresses: from genes to the field. J. Exp Bot. 63, 3523-3543. doi: 10.1093/jxb/ers 100

Bates, L. S., Waldren, R. P., and Teare, I. D. (1973). Rapid determination of free proline for water stress studies. Plant Soil 39, 205-208. doi: 10.1007/BF00018060

Bertamini, M., Muthuchelian, K., and Nedunchezhian, N. (2004). Effect of grapevine leafroll on the photosynthesis of field grown grapevine plants (Vitis vinifera L. cv. Lagrein). J. Phytopathol. 152, 145-152. doi: 10.1111/j.14390434.2004.00815.x

Bolwell, G. P., Blee, K. A., Butt, V. S., Davies, D. R., Gardner, S. L., Gerrish, C., et al. (1999). Recent advances in understanding the origin of the apoplastic oxidative burst in plant cells. Free Radic. Res. 31, S137-S145. doi: 10.1080/10715769900301431

Böttcher, C., Boss, P. K., and Davies, C. (2011). Acyl substrate preferences of an IAA-amido synthetase account for variations in grape (Vitis vinifera L.) berry ripening caused by different auxinic compounds indicating the importance of auxin conjugation in plant development. J. Exp. Bot. 62, 4267-4280. doi: 10.1093/jxb/err134

Böttcher, C., Burbidge, C. A., Boss, P. K., and Davies, C. (2013). Interactions between ethylene and auxin are crucial to the control of grape (Vitis vinifera L.) berry ripening. BMC Plant Biol. 13:222. doi: 10.1186/14712229-13-222

Bradford, M. M. (1976). A rapid and sensitive method for the quantization of microgram quantities of protein utilizing the principle of protein-dye binding. Anal. Biochem. 72, 248-254. doi: 10.1016/0003-2697(76)90527-3

Chaves, M. M., Santos, T., Souza, C. R., Ortuño, M. F., Rodrigues, M. L., Lopes, C., et al. (2007). Deficit irrigation in grapevine improves water-use efficiency while controlling vigour and production quality. Ann. Appl. Biol. 150, 237-252. doi: 10.1111/j.1744-7348.2006.00123.x

Christov, I., Stefanov, D., Velinov, T., Goltsev, V., Georgieva, K., Abracheva, P., et al. (2007). The symptomless leaf infection with grapevine leafroll associated virus 3 in grown in vitro plants as a simple model system for investigation of viral effects on photosynthesis. J. Plant Physiol. 164, 1124-1133. doi: 10.1016/j.jplph.2005.11.016

Chutia, J., and Borah, S. P. (2012). Water stress effects on leaf growth and chlorophyll content but not the grain yield in traditional rice (Oryza sativa Linn.) genotypes of Assam, India II. Protein and proline status in seedlings under PEG induced water stress. Am. J. Plant Sci. 3, 971-980. doi: 10.4236/ajps.2012.37115

Cui, Z. H., Bi, W. L., Chen, P., Xu, Y., and Wang, Q. C. (2015). Abiotic stress improves in vitro biological indexing of Grapevine leafroll-associated virus3 in red grapevine cultivars. Aust. J. Grape Wine Res. 21, 490-495. doi: 10.1111/ajgw.12146 manuscript revision. QW design of the experiment, revision of the manuscript and the financial support.

\section{ACKNOWLEDGMENTS}

The authors gratefully acknowledge financial supports through "948" program from State Forestry Administration of China (project No. 2013-4-41) and through from Department of Science \& Technology of Shaanxi Province of China (Project No. 2013KTCL02-01).
Dami, I., and Hughes, H. G. (1997). Effects of PEG-induced water stress on in vitro hardening of 'Valiant' grape. Plant Cell Tiss. Org. Cult. 47, 97-101. doi: 10.1007/BF02318944

Davies, C., and Robinson, S. (1996). Sugar accumulation in grape berries: cloning of two putative vacuolar invertase cDNAs and their expression in grapevine tissues. Plant Physiol. 111, 275-283.

del Pozo, O., and Lam, E. (2003). Expression of the baculovirus p35 protein in tobacco affects cell death progression and compromises $\mathrm{N}$ gene-mediated disease resistance response to Tobacco mosaic virus. Mol. Plant Microbe Interact. 16, 485-494. doi: 10.1094/MPMI.2003.16.6.485

Dobrev, P. I., Haviček, L., Vágner, M., Malbeck, J., and Kaminek, M. (2005). Purification and determination of plant hormones auxin and abscisic acid using solid phase extraction and two-dimensional high performance liquid chromatography. J. Chromat. A. 1075, 159-166. doi: 10.1016/j.chroma.2005.02.091

Duan, Y. F., Zhang, W. S., Li, B., Wang, Y. N., Li, K. X., Sodmergen, et al. (2010). An endoplasmic reticulum response pathway mediates programmed cell death of root tip induced by water stress in Arabidopsis. New Phytol. 186, 681-695. doi: 10.1111/j.1469-8137.2010.03207.x

Evans, C., Malin, G., Graham, P., and Mills, G. P. (2006). Viral infection of Emiliania huxleyi (Prymnesiophyceae) leads to elevated production of reactive oxygen species. J. Phycol. 42, 1040-1047. doi: 10.1111/j.1529-8817.2006.00256.x

Faraloni, C., Cutino, I., Petruccelli, R., Leva, A. R., Lazzeri, S., and Torzillo, G. (2011). Chlorophyll fluorescence technique as a rapid tool for in vitro screening of olive cultivars (Olea europaea L.) tolerant to drought stress. Environ. Experi. Bot. 73, 49-56. doi: 10.1016/j.envexpbot.2010.10.011

Figueiredo, M. V., Burity, H. A., Martínez, C. R., and Chanway, C. P. (2008). Alleviation of drought stress in the common bean (Phaseolus vulgaris L.) by co-inoculation with Paenibacillus polymyxa and Rhizobium tropici. Appl. Soil Ecol. 40, 182-188. doi: 10.1016/j.apsoil.2008.04.005

Fraser, R. S. S., and Whenham, R. J. (1989). Abscisic-acid metabolism in tomato plants infected with tobacco mosaic virus: relationships with growth, symptoms and the Tm-1 gene for TMV resistance. Physiol. Mol. Plant Pathol. 34, 215-226. doi: 10.1016/0885-5765(89)90045-3

Fu, Q. S., Li, H. L., Cui, J., Zhao, B., and Guo, Y. D. (2009). Effects of water stress on photosynthesis and associated physiological characters of Capsicum annuum $\mathrm{L}$. Sci. Agric. Sin. 42, 1859-1866. doi: 10.3864/j.issn.0578-1752.2009.05.046

Gaff, D. F., and Okong'O-Ogola, O. (1971). The use of non-permeating pigments for testing the survival of cells. J. Exp. Bot. 22, 756-758.

Gara, L. D., de Pinto, M. C., and Tommasi, F. (2003). The antioxidant systems visà-vis reactive oxygen species during plant-pathogen interaction. Plant Physiol. Biochem. 41, 863-870. doi: 10.1016/S0981-9428(03)00135-9

Gill, S. S., and Tuteja, N. (2010). Reactive oxygen species and antioxidant machinery in abiotic stress tolerance in crop plants. Plant Physiol. Biochem. 48, 909-930. doi: 10.1016/j.plaphy.2010.08.016

Gonçalves, L. S. A., Rodrigues, R., Diz, M. S. S., Robaina, R. R., do Amaral Júnior, A. T., Carvalho, A. O., et al. (2013). Peroxidase is involved in Pepper yellow mosaic virus resistance in Capsicum baccatum var. Pendulum. Genet. Mol. Res. 12, 1411-1420. doi: 10.4238/2013.April.26.3

Greenberg, J. T., and Yao, N. (2004). The role and regulation of programmed cell death in plant-pathogen interactions. Cell. Microbiol. 6, 201-211. doi: 10.1111/j.1462-5822.2004.00361.x 
Hadidi, A., and Barba, M. (2011). "Economic impact of pome and stone fruit viruses and viroids," in Virus and Virus-like Diseases of Pome and Stone Fruits, eds A. Hadidi, M. Barba, T. Candresse, and W. Jelkman (St. Paul, MN: American Phyto pathological Society), 1-7.

Haq, I. U., Nazia, P., Muhammad, T. R., and Muhammad, U. D. (2012). Comparative characteristics of micropropagated plantlets of banana from BBTV-infected explants to its normal and saline stressed cultures. Pak. J. Bot. $44,1127-1130$

Hsiao, T. C. (1970). Rapid changes in the levels of polyribosomes in Zea mays in response to water stress. Plant Physiol. 46, 281-285. doi: 10.1104/pp.46.2.281

Huang, X., Yin, C., Duan, B., and Li, C. (2008). Interactions between drought and shade on growth and physiological traits in Populus Cathayana populations. Can. J. Forest Res. 38, 1877-1887. doi: 10.1139/X08-040

Jameson, P. E., and Clarke, S. F. (2002). Hormone-virus interactions in plants. Crit. Rev. Plant Sci. 21, 205-228. doi: 10.1080/0735-260291044241

Khristov, I. K., Stefanov, D., Goltsev, V. N., and Abrasheva, P. (2001). Effects of grapevine fanleaf and stem pitting viruses on the photosynthetic activity of grapevine plants grown in vitro. Russ. J. Plant Physiol. 48, 473-477. doi: 10.1023/A:1016799329371

Kieffer, M., Neve, J., and Kepinski, S. (2010). Defining auxin response contexts in plant development. Curr. Opin. Plant Biol. 13, 12-20. doi: 10.1016/j.pbi.2009.10.006

Kyseláková, H., Sedlářová, M., Kubala, M., Nožková, V., Piterková, J., Luhová, L., et al. (2013). Reactive oxygen and nitrogen species and hormone signalling in systemic infection of pea by Pea enation mosaic virus. Plant Protect. Sci. 49, 105-119.

Li, J. W., Wang, B., Song, X. M., Wang, R. R., Zhang, H., Zhang, Z. B., et al. (2013). Potato leafroll virus (PLRV) and Potato virus Y (PVY) influence vegetative, physiological metabolism of in vitro-cultured shoots of potato (Solanum tuberosum L.). Plant Cell Tiss. 114, 313-324. doi: 10.1007/s11240-013-0327-X

Li, Y., Zhao, H., Duan, B., Korpelainen, H., and Li, C. (2011). Effect of drought and ABA on growth, photosynthesis and antioxidant system of Cotinus coggygria seedlings under two different light conditions. Environ. Exp. Bot. 71, 107-113. doi: 10.1016/j.envexpbot.2010.11.005

Livak, K. J., and Schmittgen, T. D. (2001). Analysis of relative gene expression data using real-time quantitative PCR and the 2(-Delta Delta C (T)) method. Methods 25, 402-408. doi: 10.1006/meth.2001.1262

Lockhart, B. E., and Semancik, J. S. (1970). Growth inhibition, peroxidase and 3-indoleacetic acid oxidase activity and ethylene production in cowpea mosaic virus infected cowpea seedlings. Phytopathology 60, 553-554. doi: 10.1094/Phyto-60-553

Lokhande, V. H., Nikam, T. D., Patade, V. Y., Ahire, M. L., and Suprasanna, P. (2011). Effects of optimal and supra-optimal salinity stress on antioxidative defence, osmolytes and in vitro growth responses in Sesuvium portulacastrum L. Plant Cell Tiss. Organ. Cult. 104, 41-49. doi: 10.1007/s11240-010-9802-9

Lokhande, V. H., Nikam, T. D., and Penna, S. (2010). Biochemical, physiological and growth changes in response to salinity in callus cultures of Sesuvium portulacastrum L. Plant Cell Tiss. Organ. Cult. 102, 17-25. doi: 10.1007/s11240010-9699-3

Lu, S., Peng, X., Guo, Z., Zhang, G., Wang, Z., Wang, C., et al. (2007). In vitro selection of salinity tolerant variants from triploid bermudagrass (Cynodon transvaalensis $\mathrm{x}$ C. dactylon) and their physiological responses to salt and drought stress. Plant Cell Rep. 26, 1413-1420. doi: 10.1007/s00299-007-0339-2

Marković, Z., Preiner, D., Bošnjak, A. M., Safner, T., Stupić, D., Andabaka, Ž., et al. (2014). In vitro introduction of healthy and virus-infected genotypes of native Croatian grapevine cultivars. Cent. Eur. J. Biol. 9, 1087-1098. doi: 10.2478/s11535-014-0337-7

Maroco, J. P., Rodrigues, M. L., Lopes, C., and Chaves, M. (2002). Limitations to leaf photosynthesis in field-grown grapevine under drought-metabolic and modeling approaches. Funct. Plant Biol. 29, 451-459. doi: 10.1071/PP01040

Martelli, G. P. (2012). “Grapevine virology highlights: 2010-2012,” in Proceedings of the 17th Congress of ICVG (Davis, CA), 13-31.

Masia, A. (2003). "Physiological effects of oxidative stress in relation to ethylene in postharvest produce," in Postharvest Oxidative Stress in Horticultural Crops, ed D. M. Hodges (New York, NY: Food Products Press), 165-197.

Michel, B. L. (1983). Evaluation of the water potentials of solutions of polyethylene glycol 8000 both in the absence and presence of other solutes. Plant Physiol. 72, 66-70. doi: 10.1104/pp.72.1.66
Moutinho-Pereira, J., Correia, C. M., Gonclve, B., Bacelar, E. A., Coutinho, J. F., Ferreira, H. F., et al. (2012). Impacts of leafroll-associated viruses (GLRaV1 and -3 ) on the physiology of the Portuguese grapevine cultivar 'Touriga Nacional' growing under field conditions. Annu. Appl. Biol. 160, 237-249. doi: 10.1111/j.1744-7348.2012.00536.x

Murashige, T., and Skoog, F. (1962). A revised medium for rapid growth and bioassays with tobacco cell cultures. Physiol. Plant. 15, 473-497. doi: 10.1111/j.1399-3054.1962.tb08052.x

Noctor, G., Mhamdi, A., and Foyer, C. H. (2014). Roles of reactive oxygen metabolism in drought: not so cut and dried. Plant Physiol. 164, 1636-1648. doi: 10.1104/pp.113.233478

Padder, B. A. (2014). Plant disease resistance genes: from perception to signal transduction. Plant Signal. 20, 345-354. doi: 10.1007/978-81-322-1542-4_20

Parida, A. K., Dagaonkar, V. S., Phalak, M. S., Umalkar, G. V., and Aurangabadkar, L. P. (2007). Alterations in photosynthetic pigments, protein and osmotic components in cotton genotypes subjected to short-term drought stress followed by recovery. Plant Biotech. Rep. 1, 37-48. doi: 10.1007/s11816-0060004-1

Patade, V. Y., Suprasanna, P., and Bapat, V. A. (2008). Effects of salt stress in relation to osmotic adjustment on sugarcane (Saccharum officinarum L.) callus cultures. Plant Growth Regul. 55, 169-173. doi: 10.1007/s10725-0089270-y

Permar, V., Singh, A., Pandey, V., Alatar, A. A., Faisal, M., Jain, R. K., et al. (2014). Tospo viral infection instigates necrosis and premature senescence by micro RNA controlled programmed cell death in Vigna unguiculata. Physiol. Mol. Plant Pathol. 88, 77-84. doi: 10.1016/j.pmpp.2014.09.004

Prasch, C. M. (2013). Simultaneous application of heat, drought, and virus to A rabidopsis plants reveals significant shifts in signaling networks. Plant Physiol. 162, 1849-1866. doi: 10.1104/pp.113.221044

Qaderi, M. M., Kurepin, L. V., and Reid, D. M. (2006). Growth and physiological responses of canola (Brassica napus) to three components of global climate change: temperature, carbon dioxide and drought. Physiol. Plant. 128, 710-721. doi: 10.1111/j.1399-3054.2006.00804.x

Radwan, D. E. M., Fayez, K. A., Mahmoud, S. Y., Hamad, A., and Lu, G. Q. (2007). Physiological and metabolic changes of Cucurbita pepo leaves in response to zucchini yellow mosaic virus (ZYMV) infection and salicylic acid treatments. Plant Physiol. Biochem. 45, 480-489. doi: 10.1016/j.plaphy.2007. 03.002

Rajagopal, R. (1977). Effect of tobacco mosaic virus infection on the endogenous levels of indoleacetic, phenylacetic and abscisic acids of tobacco leaves in various stages of development. Z. Pflanzenphysiol. 83, 403-409. doi: 10.1016/S0044-328X(77)80046-9

Rao, M. R. K., and Narasimham, B. (1974). Endogenous auxin levels as influenced by infectious variegation' in Lisbon lemon leaves. South Ind. Hort. 22, 138-139.

Ren, F., Dong, Y.-F., Zhang, Z.-P., Fan, X.-D., Hu, G.-J., and Zhu, H.-J. (2013). Review of advances and perspectives in virus-resistant transgenic grapevine studies. J. Hortic. Sci. 40, 1633-1644.

Romero-Puertas, M. C., Rodríguez-Serrano, M., Corpas, F. J., Gomezó, M., del Río, L. A., and Sandalio, L. M. (2004). Cadmium-induced subcellular accumulation of $\mathrm{O}^{2-}$ and $\mathrm{H}_{2} \mathrm{O}_{2}$ in pea leaves. Plant Cell Environ. 27, 1122-1134. doi: 10.1111/j.1365-3040.2004.01217.x

Sampol, B., Bota, J., Riera, D., Medrano, H., and Flexas, J. (2003). Analysis of the virus-induced inhibition of photosynthesis in malmsey grapevines. New Phytol. 160, 403-412. doi: 10.1046/j.1469-8137.2003.00882.x

Smith, S. H., McCall, S. R., and Harris, J. H. (1968). Auxin transport in curly top virus-infected tomato. Phytopathology 58, 1669-1670.

Sullivan, C. Y. (1972). "Mechanism of heat and drought resistance in grain sorghum and methods of measurement," in Sorghum in the seventie, eds N. G. P. Raoand and L. R. House(New Delhi: Oxford and IBH), 247-264.

Sun, J., Guo, J., Zeng, J., Han, S., Song, A., Chen, F., et al. (2013). Changes in leaf morphology, antioxidant activity and photosynthesis capacity in two different drought-tolerant cultivars of chrysanthemum during and after water stress. Sci. Hortic. 161, 249-258. doi: 10.1016/j.scienta.2013.07.015

Suzuki, N., Rivero, R. M., Shulaev, V., Blumwald, E., and Mittler, R. (2014). Abiotic and biotic stress combinations. New Phytol. 203, 32-43. doi: 10.1111/nph. 12797

Swarup, R., and Péret, B. (2012). AUX/LAX family of auxin influx carriers - an overview. Front. Plant Sci. 3:225. doi: 10.3389/fpls.2012.00225 
Tanne, E., Spiegel-Roy, P., and Shlamovitz, N. (1996). Rapid in vitro indexing of grapevine viral diseases: the effect of stress-inducing agents on the diagnosis of leafroll. Plant Dis. 80, 72-974. doi: 10.1094/P.D.80-0972

UNESCO Water Portal (2007). Available online at: http://www.unesco.org/water (Accessed 25 October 2007).

Wang, S.-M., Hou, X.-L., Ying, L., Cao, X.-W., Zhang, S., and Wang, F. (2011). Effects of Turnip mosaic virus (TuMV) on endogenous hormones and transcriptional level of related genes in infected non-heading Chinese cabbage. J. Nanjing Agric. Univ. 5, 13-19. doi: 10.7685/j.issn.1000-2030.2011. 05.003

Watanabe, S., Kojima, K., Ide, Y., and Sasaki, S. (2000). Effects of saline and osmotic stress on proline and sugar accumulation in Populus euphratica in vitro. Plant Cell Tiss. 63, 199-206. doi: 10.1023/A:1010619 503680

Wheeler, S., Loveys, B., Ford, C., and Davies, C. (2009). The relationship between the expression of abscisic acid biosynthesis genes, accumulation of abscisic acid and the promotion of Vitis vinifera L. berry ripening by abscisic acid. Aust. J. of Grape Wine Res. 15, 195-204. doi: 10.1111/j.1755-0238.2008. 00045.x

Woodward, A. J., and Bennett, I. J. (2005). The effect of salt stress and abscisic acid on proline production, chlorophyll content and growth of in vitro propagated shoots of Eucalyptus camaldulensis. Plant Cell Tiss. 82, 189-200. doi: 10.1007/s11240-005-0515-4
Xu, P., Chen, F., Mannas, J. P., Feldman, T., Sumner, L. W., and Roossinck, M. J. (2008). Virus infection improves drought tolerance. New Phytol. 180, 911-921. doi: 10.1111/j.1469-8137.2008.02627.x

Zhang, K., Song, Y. P., Wang, Y., Li, K., Gao, L., Zhong, Y. K., et al. (2014). Differential necrotic lesion formation in soybean cultivars in response to Soybean mosaic virus. Eur. J. Plant Pathol. 139, 525-534. doi: 10.1007/s10658014-0408-7

Zhang, N., Zhao, B., Zhang, H. J., Weeda, S., Yang, C., Yang, Z. C., et al. (2013). Melatonin promotes water-stress tolerance, lateral root formation, and seed germination in cucumber (Cucumis sativus L.). J. Pineal Res. 54, 15-23. doi: 10.1111/j.1600-079X.2012.01015.x

Zhu, J. K. (2002). Salt and drought stress signal transduction in plants. Annu. Rev. Plant Biol. 53, 247-273. doi: 10.1146/annurev.arplant.53.091401.143329

Conflict of Interest Statement: The authors declare that the research was conducted in the absence of any commercial or financial relationships that could be construed as a potential conflict of interest.

Copyright (C) $2016 \mathrm{Cui}, \mathrm{Bi}, \mathrm{Hao}, \mathrm{Xu}, \mathrm{Li}$, Walker and Wang. This is an open-access article distributed under the terms of the Creative Commons Attribution License (CC $B Y)$. The use, distribution or reproduction in other forums is permitted, provided the original author(s) or licensor are credited and that the original publication in this journal is cited, in accordance with accepted academic practice. No use, distribution or reproduction is permitted which does not comply with these terms. 